https://helda.helsinki.fi

How to... get started with theory in education

\author{
Johnston, Jenny
}

2018-08

Johnston , J , Bennett , D \& Kajamaa , A 2018 , ' How to... get started with theory in

education ' , The clinical teacher, vol. 15 , no. 4 , pp. 294-297 . https://doi.org/10.1111/tct.12918

http://hdl.handle.net/10138/326197

https://doi.org/10.1111/tct.12918

acceptedVersion

Downloaded from Helda, University of Helsinki institutional repository.

This is an electronic reprint of the original article.

This reprint may differ from the original in pagination and typographic detail.

Please cite the original version. 
To cite: Johnston, J., Bennett, D. \& Kajamaa, A. (2018). How to... get started with theory in education. The Clinical Teacher 15, 294-297. doi: 10.1111/tct.12918

\section{How to... get started with theory in education}

Jennifer Johnston1, Deirdre Bennett2, Anu Kajamaa3

1 Centre for Medical Education, Queen's University Belfast

2 Medical Education Unit, University College Cork

3 Faculty of Educational Sciences, University of Helsinki

\section{Introduction}

Clinicians who undertake education research may find themselves in unfamiliar territory. Long-held beliefs may be challenged by new ways of thinking and talking about research. In this new intellectual landscape, informed by multiple disciplines, theory looms large and can seem off-putting, or even overwhelming. In this paper, we aim to unravel some of the complexity of theory, challenging any mystique and making it more accessible. We will show how theoretically informed research can shed light on health professional education topics and can be accessible even to beginners.

Mouly described theory as 'a convenience - a necessity really - organising a whole slough of assorted facts, laws, concepts, constructs, principles, into a meaningful and manageable form. ${ }^{1}$ Theory can simply be thought of as a guide or a tool which provides an explanation of something, helping us to make sense of the world. There are lots of different fields of research which use theory, such as education and psychology. Theory derived from these disciplines, and others, may be repurposed for use in medical education research. ${ }^{2}$ Theories are like lenses through which to see the world, bringing fuzzy objects into clear focus and helping researchers to see up close or into the distance. Different lenses show up different things to the researcher, so it is sensible to pick a theory which makes sense with the research question. The researcher can choose between using an existing theoretical perspective (deductive approach) or even to build theory (inductive approach). We will discuss both of these choices in greater detail below.

\section{Different levels of theory}

Dividing theory into three tiers - grand, mid-range, and low-level-creates a useful framework for understanding the role of each in research. ${ }^{3}$ All three may be present in one research project, each aligning with the others but contributing something different. 
At the most overarching level are grand theories. These try and explain everything, making broad, overarching statements about the world. ${ }^{4}$ Sometimes, grand theories can be so commonplace that they become all but invisible. For example, the scientific method and evidence-based medicine are derived from a grand theory termed positivism. The main premise of positivism is that objective research evidence will lead humankind to a full understanding of the world around us. ${ }^{5}$ While many healthcare professionals will recognise and espouse this way of thinking, it is less often recognised as a theory; a glance at any major medical journal will show that the typical randomised controlled trial makes no mention of any theoretical perspective. ${ }^{6}$ There are also other grand theories, used in social science disciplines, which describe human practices and processes in different ways and stress the significance of observations and interpretations. Interpretivism is one which focuses more on the role of the researcher in constructing knowledge, and which accepts that individuals may each experience the world differently. ${ }^{7}$ Interpretivism is quite a common perspective in medical education research, ${ }^{8}$ because it accommodates the coexistence of different worldviews and constructions of the social world, and is used by the authors in their work.

Low-level theory is at the other end of the spectrum, and consists of our own mooted explanations of things. If grand theory tries to explain everything, low-level theory is specific in its explanatory power. We all make our own informal working theories to explain the events of everyday life. Perhaps, for example, you might theorise that, in your experience, students learn better from interacting with patients rather than from watching you consult. While not generalisable, this type of theory is really useful in providing a working hypothesis which can then be tested, explored or explicated formally in research.

Connecting these two different types of explanation are mid-range theories, which bridge the gap between overarching explanations and empirical observations. ${ }^{3}$ They provide abstracted explanations of things, yet ones which are still grounded in research data. Midrange theories do not try to make broad statements like grand theories, but they allow indepth explanations within particular contexts. A mid-range theory is usually aligned with a grand theory whose fundamental assumptions it shares, so that they make sense together. There are lots of different mid-range theories, so these are commonly cited in papers, and are practically useful types of theory for the medical education researcher. Examples of midrange theories are the theory of planned behaviour (a positivist theory, commonly used in public health research) ${ }^{9}$ and communities of practice theory (a social learning theory popular in medical education). ${ }^{10}$

\section{Grounded theory}

An alternative option is to become a theorist yourself, building your own mid-range theory using grounded theory. ${ }^{11} 12$ This offers well-published steps, with slightly different methods for positivist and interpretivist research. ${ }^{12}$ In this case, your research is not directed by any 
other theory. Instead, the theory is built from the data. The researcher engages in several rounds of concurrent data collection and analysis. At every step, the explanations become increasingly sophisticated and abstract, until you have developed a model which offers an explanation of a particular phenomenon within a particular context, and which is potentially transferrable to other similar contexts (in other words, a mid-range theory). Grounded theory has been successfully used in medical education. ${ }^{13} 14$

\section{How to choose and use theory}

Perhaps the biggest challenge lies in getting the right sort of theory for your research. For the busy clinician, this may seem like an enormous hurdle to begin with. Yet a basic understanding of the 'rules' of theory use, along with some familiarity with major health professions education journals, will go a long way to understand what other researchers have done. From there, the researcher can make their own forays into theory-driven research.

As with evidence-based medicine, it is essential that the chosen theory and methods work well together with the research question. The questions which can be asked will depend first of all on which grand theory the researcher espouses: positivist research lends itself well to measuring, observing and 'what' questions, while interpretivist research lends itself to analysis of context, process and 'how' or 'why' questions. ${ }^{15}$ This in turn will dictate the sort of theory and methods which might be most useful. Are you looking at cognitive performance in OSCEs (objective structured clinical examinations)? Then perhaps psychometrics and statistical analysis are your friend. Are you researching professional culture and identity? Then consider sociocultural learning theory and semi-structured interviews. Congruence between the different underpinning theories, the research question, methodology and methods is an essential part of designing a rigorous piece of work. ${ }^{8}$ Developing an overview of the sorts of theory which are commonly used in your field will enhance your ability to choose and apply a theory, and to understand how others have used it. In that sense, theory use for educational research is somewhat analogous to understanding statistics and critical appraisal for positivist research.

Once you have chosen a theory and appropriate research question, consider how you would like to use the perspective you have chosen. You may choose a 'light touch' approach, where theoretical concepts simply sensitise your analysis. For qualitative data, you might for example use an inductive thematic analysis, ${ }^{16}$ but keep some of the main concepts you have read about in mind as you do so. Or you might choose a heavily theoretically driven approach, using (for example) a framework analysis to code for particular aspects within the data that you have identified a priori. ${ }^{17}$ Either way, the intention is to use a particular lens to see particular things. We have given three examples of different ways in which we have used theory in our own research (see table 1). 
When might you choose to induce your own theory from data? To an extent, this is a matter of personal choice, but grounded theory is especially useful for looking at processes and for examining interrelationships between things. ${ }^{12}$ Because grounded theory does not presume any prior knowledge of theory, it may seem somewhat more accessible to the novice researcher. It is essential, however, to stick with the branch of grounded theory you are using. There are three: the original taking a relatively positivist view, ${ }^{18}$ the third an interpretivist view, ${ }^{12}$ and the second occupying a middle ground. ${ }^{19}$ It is also vital to adhere to the proper procedures for each of the three, which are well published-it is these which distinguish grounded theory methodology from thematic analysis. Grounded theory approaches must thus be undertaken with care, and are not necessarily an easy choice!

Table 1. Examples of how to use theory

\begin{tabular}{|c|c|}
\hline Paper & Use of theory \\
\hline $\begin{array}{l}\text { Bennett D, Kelly M, O’Flynn S. Framework } \\
\text { for feedback: the peer mini-clinical } \\
\text { examination as a formative assessment } \\
\text { tool. Medical Education } 2012: 46 ; 512 .{ }^{20}\end{array}$ & $\begin{array}{l}\text { We used qualitative methods to explore students' } \\
\text { perceptions of peer assessment. Social cognitive } \\
\text { theory (Bandura) }{ }^{21} \text { was a sensitising influence in the } \\
\text { analysis and interpretation of the findings. This is an } \\
\text { example of a 'light touch' approach to the use of } \\
\text { theory. }\end{array}$ \\
\hline $\begin{array}{l}\text { Kajamaa A, Hilli A. Clients' Initiatives and } \\
\text { Caregivers' Responses in the Organizational } \\
\text { Dynamics of Care Delivery. Qualitative } \\
\text { Health Research 2014:24(1);18-32. }{ }^{22}\end{array}$ & $\begin{array}{l}\text { We conducted a data-driven analysis and developed } \\
\text { a typology of client-caregiver encounters in health } \\
\text { care. The typology was interpreted by using activity- } \\
\text { theoretical concepts of the three levels of activity } \\
\text { (Leont'ev) }{ }^{23} \text { and the concepts of object and } \\
\text { contradiction. }{ }^{24} \text { This is an example of a fully } \\
\text { theoretically- driven approach. }\end{array}$ \\
\hline $\begin{array}{l}\text { Johnston J. L., Lundy G., McCullough M. and } \\
\text { Gormley G. J. The view from over there: } \\
\text { reframing the OSCE through the experience } \\
\text { of standardised patient raters. Medical } \\
\text { Education 2013:47(9);899-909. }{ }^{25}\end{array}$ & $\begin{array}{l}\text { Here, rather than choosing a theoretical framework, } \\
\text { we used a grounded theory approach to 'build' an } \\
\text { explanation of how standardised patients award } \\
\text { scores in OSCEs. We used Charmaz's version, known } \\
\text { as constructivist grounded theory. }{ }^{12} \text { This is an } \\
\text { example of grounded theory use in medical } \\
\text { education. }\end{array}$ \\
\hline
\end{tabular}

\section{Conclusion}

To conclude, we reiterate that theory, at whatever level it is pitched, is simply there to help see the world a little differently. We have tried to remove some of the fear and mystery that may surround the meaning and use of theory. Health professional education research questions can be illuminated by looking at them through different theoretical lenses, or answered by researchers building theories of their own. While it is always helpful to find a 
mentor with more experience, not everyone will have access to this resource. Do not be put off: read, write, learn from peers, and experiment. At every medical education conference, you will likely find enthusiasts happy to advise about how you could utilise certain theories. For those undertaking postgraduate research, there is also a vibrant theory community on social media: for example, try @socialtheoryapp, @theoryschool and even @averytheoryxmas, all on Twitter. Engaging with theory need not be daunting. Instead, it can open up a whole new world of research possibilities.

\section{Acknowledgements}

We thank Esther Helmich, Aileen Barrett, Anne de la Croix, and Terese Stenfors for providing feedback on the draft manuscript. They, together with the authors, form a research network named the European Centre of Excellence in Qualitative Study and Inquiry in Training and Education (EXQUISITE), led by Esther Helmich at University of Groningen.

\footnotetext{
${ }^{1}$ Mouly G. Educational research: the art and science of investigation. Boston, Allyn and Bacon: 1978

${ }^{2}$ Eraut M. The many meanings of theory and practice. Learning in Health and Social Care 2003: 2(2):61-65

${ }^{3}$ Merton RK. Social theory and social structure. New York, The Free Press: 1949

${ }^{4}$ Mills CW. The Sociological Imagination. New York, Oxford University Press: 1959

${ }^{5}$ Bensing, J. Bridging the gap. Patient Education and Counseling . 2000:39(1);17 - 25

${ }^{6}$ Colquhoun HL, Brehaut JC, Sales A, et al. A systematic review of the use of theory in randomized controlled trials of audit and feedback. Implementation Science 2013;8:66.

7 Bunniss S, Kelly DR. Research paradigms in medical education research. Med Educ 2010: 44: 358-366

8 Tai J, Ajjawi R. Undertaking and reporting qualitative research. Clin Teach 2016:13;175-182

${ }^{9}$ Montanaro, E. A., \& Bryan, A. D. Comparing theory-based condom interventions: Health belief model versus theory of planned behavior. Health Psychology 2014:33(10);1251-1260.

${ }^{10}$ Kitto, S.C., Grant, R.E., Peller, J. et al. What's in a name? Tensions between formal and informal communities of practice among regional subspecialty cancer surgeons. Adv in Health Sci Educ 2018;23(1):95-113

${ }^{11}$ Watling CJ, Lingard L. Grounded theory in medical education research: AMEE Guide No. 70. Med Teach. 2012;34(10):850-61.

${ }^{12}$ Charmaz K. Constructing Grounded Theory: A Practical Guide through Qualitative Analysis. Sage, London:2006

13 Taylor, TS, Nisker, J, Teunissen, P; Dornan, T, Lingard, L. Recovery of Sleep or Recovery of Self? A Grounded Theory Study of Residents' Decision Making Regarding How to Spend Their Nonclinical Postcall Time. Academic Medicine 2016(91):3;395-400

${ }^{14}$ Helmich, E., Diachun, L., Joseph, R., LaDonna, K., Noeverman-Poel, N., Lingard, L., Cristancho, S. 'Oh my God, I can't handle this!': trainees' emotional responses to complex situations. Med Educ 2018:52;206-215.

${ }^{15}$ Mattick K, Johnston J, De La Croix A. How to...write a good research question. Clin Teach 2018:15(2);104-108

${ }^{16}$ Clarke, V, Braun, V. Teaching thematic analysis: Overcoming challenges and developing strategies for effective learning. The Psychologist 2013:26(2);120-123.

${ }^{17}$ Gale NK, Heath G, Cameron E et al. Using the framework method for the analysis of qualitative data in multidisciplinary health research. BMC Med Res Methodol 2013;13:117.

${ }^{18}$ Glaser B, Strauss A. The discovery of grounded theory: strategies for qualitative research. New Brunswick, Aldin Transaction: 1967

${ }^{19}$ Strauss A, Corbin, J. Basics of qualitative research: Grounded theory procedures and techniques. Thousand Oaks, Sage Publications: 1990
} 
${ }^{20}$ Bennett, D., Kelly, M. and O'Flynn, S. Framework for feedback: the peer mini-clinical examination as a formative assessment tool. Medical Education 2012:46;512

${ }^{21}$ Bandura, A., National Inst of Mental Health. Social foundations of thought and action: A social cognitive theory. Englewood Cliffs, NJ: Prentice-Hall: 1986

${ }^{22}$ Kajamaa, A. \& Hilli, A. Clients' Initiatives and Caregivers' Responses in the Organizational Dynamics of Care Delivery. Qualitative Health Research 2014:24(1);18-32.

23 Leont'ev, A. N. Activity, consciousness and personality. Prentice-Hall, Englewood Cliffs, NJ: 1978

${ }^{24}$ Engeström, Y., Sannino, A. Discursive manifestations of contradictions in organizational change efforts: A methodological framework. Journal of Organizational Change Management 2011:24(3);368-387.

25 Johnston JL, Lundy G, McCullough M, Gormley GJ. The view from over there: reframing the OSCE through the experience of standardised patient raters. Medical Education 2013;47(9):899-909 